\title{
DEVELOPMENTS IN SURGERY
}

VOLUME 11

The titles published in this series are listed at the end of this volume. 


\section{ORGAN}

TRANSPLANTATION

1990

edited by

G. M. ABOUNA

M. S. A. KUMAR (Associate Editor)

and

A. G. WHITE (Associate Editor)

Department of Organ Transplantation

Kuwait University.

Kuwait City, Kuwait.

and

The Division of Transplantation

Department of Surgery

Hahnemann University

Philadelphia, PA. U.S.A. 


\section{Contents}

Foreword by Anthony P. Monaco $\quad$ xv

Preface by George M. Abouna xvii

List of contributors xix

Part One: Historical Reflections

1. Reflections on the development of organ transplantation H.M. Lee

Part Two: Immunology of Organ Transplantation

2. Cellular and molecular mechanisms of allograft rejection Pekka Häyry

3. What does the alloreactive $T$ cell see?

J.R. Batchelor, G. Lombardi and R.I. Lechler

4. HLA matching and organ transplantation David W. Gjertson and Paul I. Terasaki

5. An effective strategy for transplantation of highly sensitized patients F.H.J. Claas, L.P. de Waal, J. Beelen, P. Reekers, P. van den BergLoonen, E. de Gast, J. D'Amaro, G.G. Persijn, F. Zantvoort and J.J. Van Rood

6. Rapid lymphocyte crossmatching for renal transplantation A.G. White, K.T. Raju, M.S.A. Kumar, E.M. Philips and G.M. Abouna

Part Three: Organ Allograft Rejection

7. Fifteen-year experience with fine needle aspiration biopsies at the University of Helsinki

Pekka Häyry, Eeva von Willebrand and Irmeli Lautenschlager 
8. Study of antibody specificity in highly sensitized patients using human monoclonal antibody technology

Ibrahim A. Al-Muzairai, Barbra K. Weber and David A. Power

9. Idiotypic-Antiidiotypic antibody interaction and renal transplant survival

I.A. Al-Muzairai, A.A. MacLeod, M. MacMillan, K.N. Stewart and G.R.D. Catto

Part Four: Immunosuppression

10. Transplantation and blood transfusion in 1990 Robert J. Corry

11. Quadruple-drug immunosuppressive induction treatments for immunological high-risk patients in cadaveric renal transplantation using poly- and monoclonal antibodies

H. Schneeberger, S. Schleibner, L. Friedl, M. Schilling, W.D. Illner, D. Abendroth and W. Land

12. Sequential combination immunotherapy for cadaveric renal transplantation: OKT3 versus rabbit ATG induction

M.P. Posner, H.F. Henriques, A.L. King, Y. Berlatzky, C. Klosterman, B.A.D. Cook and H.M. Lee

13. Multi-organ transplant experience with $\mathrm{OKT} 3$ and strategies for use at the University of Cincinnati Medical Center

Timothy J. Schroeder, M. Roy First and Israel Penn

14. Cyclosporine withdrawal in renal transplant recipients maintained on azathioprine, prednisone and cyclosporine

M. Kalawi, N.A. Al-Sabawi, M. Samhan, D. Panjwani, M.S.A. Kumar, E.M. Philips and G.M. Abouna

15. Early experience with FK 506 in liver transplantation

Robert D. Gordon, Satoru Todo, John J. Fung, Andreas C. Tzakis, Noriko Murase, Ashok Jain, Mario Alessiani and Thomas E. Starzl

16. Deoxyspergualin. A novel immunosuppressant: experimental and clinical studies

H. Amemiya, S. Suzuki, K. Ota, K. Takahashi, T. Sonoda, M. Ishibashi, R. Omoto, I. Koyama, K. Dohi, Y. Fukuda and K. Fukao

17. Preliminary results with FK 506 in pancreas grafting in a nonhuman primate model

G. Kootstra, B.G. Ericzon, R. Wijnen, T. Tiebosch, K. Kubota and C.-G. Groth

18. The effect of DST on graft outcome - the Turkish experience

S. Sert, H. Gulay, M. Koç and M. Haberal 
19. Induction of specific unresponsiveness (tolerance) to experimental and clinical allografts using polyclonal antilymphocyte serum and donor-specific bone marrow

Anthony P. Monaco

20. Comparison of cyclosporine assays using radioimmunoassay, fluorescent polarization immunoassay and high-performance liquid chromatography

A.G. White, D. Panjwani, M. Angelo Khattar, A.S. El-Deen, M.S.A. Kumar, E.M. Philips and G.M. Abouna

Part Five: Renal Transplantation

21. Long-term outcome in renal transplantation H. Brynger

22. Ten-year experience with 500 renal transplants G.M. Abouna, M.S.A. Kumar, A.G. White, M. Samhan, O.S.G. Silva, I.H. Al-Abdullah, M. Kalawi, S. Al-Dadah, N. Al-Sabawi, P. John and E. M. Philips

23. Long-term results in recipients of cadaveric renal allografts under cyclosporine therapy

S. Schleibner, H. Schneeberger and W. Land

24. Transplantation of single and double kidneys from pediatric donors David E.R. Sutherland, Rainer W.G. Gruessner, Arthur J. Matas, Goncal Lloveras, David S. Fryd, David L. Dunn, William D. Payne and John S. Najarian

25. ABO-incompatible living related donor transplantation

M. Haberal, H. Gulay, S. Sert, G. Arslan, M. Koç and N. Bilgin

26. The use of single pediatric cadaver kidneys for transplantation into adult recipients

G.M. Abouna, P. John, M.S.A. Kumar, A.G. White, O.S.G. Silva, E. Shuwaikh, M. Samhan, E.M. Philips and S. Al-Dadah

27. Living unrelated donor renal transplantation

S. Sert, H. Gulay, M. Koç and M. Haberal

28. Renal transplantation in Tunisia - a three-year experience

H. Ben Ayed, A. El-Matri, T. Ben Abdallah, C. Kechrid, H. Ben Maiz, A. Kheder, F. Ben Moussa, S. Smerlie, M. Ayed, M. ElOuakdi, K. Ayed and R. Bardi

29. Renal transplantation in children

M. Samhan, P. John, M.S.A. Kumar, A.G. White, O.S.G. Silva, E.

Shuwaikh, E.M. Philips, S. Al-Dadah and G.M. Abouna 
30. Kidney donors - long-term follow up

P. John, M.S.A. Kumar, H. Abdul Karim, M. Samhan, N. AlSabawi, S. Al-Dadah, T. Eche, O.S.G. Silva, E. Shuwaikh, A. Kobryn, E.M. Philips and G.M. Abouna

31. Current techniques for permanent vascular access surgery experience with 930 procedures

S. Al-Dadah, M. Kalawi, M. Samhan, P. John, M.S.A. Kumar and G.M. Abouna

32. Results of 319 consecutive renal transplants from living related and living unrelated donors in Iran

A.J. Ghods, I. Fazel, B. Nikbin, K. Rahbar, E. Abdi, H.N. Ghashti and F. Prooshani

\section{Part Six: Liver Transplantation}

33. Liver transplantation: current status

Robert D. Gordon

34. An overview of liver transplantation therapy for children

R. Patrick Wood, Byers W. Shaw Jr, Robert J. Stratta, Alan N. Langnas and Todd J. Pillen

35. Current anesthetic management in clinical liver transplantation Yoogoo Kang

36. Risk factors in adult liver transplant recipients

R. Patrick Wood, Byers W. Shaw Jr, Robert J. Stratta, Alan N. Langnas and Todd J. Pillen

37. The concept of reduced-size liver transplantation, including splitliver and living related liver transplantation

X.M. Rogiers, J.C. Emond, P.F. Whitington, T.G. Heffron, K.L. King, M.D. Yang and C.E. Broelsch

38. Immunological factors contributing to outcome in liver transplantation

Robert D. Gordon

39. Transplantation for hepatobiliary malignancies

R. Patrick Wood, Byers W. Shaw Jr, Robert J. Stratta, Alan N. Langnas and Todd J. Pillen

40. The diagnosis and management of massive blood loss during liver transplantation

Yoogoo Kang

41. Early clinical experience with cluster resection and transplantation for right upper quadrant abdominal malignancy

Robert D. Gordon, Satoru Todo, Andreas G. Tzakis and Thomas E. Starzl 
42. Lung transplantation: current techniques and outcomes

R. Morton Bolman III

43. Heart-lung transplantation at the University of Minnesota

R. Morton Bolman III

44. Specificity and sensitivity of the cytoimmunological monitoring (CIM): differentiation between cardiac rejection, viral, bacterial, or fungal infection

C. Hammer, D. Klanke, P. Dirschedl, B. M. Kemkes, B. Reichart, M. Gokel and F. Krombach

\section{Part Eight: Pancreas Transplantation}

45. International Pancreas Transplantation Registry report

David E.R. Sutherland, Kristin Gillingham and Kay C. MoudryMunns

46. Techniques and experience of pancreatic transplantation with bladder drainage

Robert J. Corry and John L. Smith

47. Pancreas transplantation in non-uremic diabetic recipients

David E.R. Sutherland, David L. Dunn, Kay C. Moudry-Munns, Kristin Gillingham and John S. Najarian

48. Early observation with pancreas transplantation using the bladder drainage procedure

W.D. Illner, D. Abendroth, H. Schneeberger, S. Schleibner, M. Stangl, J. Theodorakis, R. Landgraf and W. Land

49. Results of pancreas transplantation with irradiated spleen and segment of duodenum

G. Kootstra, J.P. Van Hooff, H. Peltenburg, C.J. van der Linden, R. Wijnen, P. van den Berg-Loonen, J.A.M. de Jong, T. Verschueren and G. Heidendal

50. Experience with pancreas transplants from living related donors David E.R. Sutherland, Frederick C. Goetz, David M. Kendall, R. Paul Robertson, Kristin Gillingham, Kay C. Moudry-Munns and John S. Najarian

Part Nine: Islet Cell Transplantation

51. Islet transplantation - the World Transplant Registry

R.G. Bretzel, B.J. Hering and K.F. Federlin 
52. Prevention of rejection of islet allografts and xenografts without continuous immunosuppression of the recipients

Paul E. Lacy and David W. Scharp

53. Effect of islet transplantation on diabetic secondary complications R.G. Bretzel

54. Does pretreatment of islets of Langerhans with deoxyguanosine improve allograft survival without immunosuppression?

I.H. Al-Abdullah, M.S.A. Kumar, M.S. Al-Adnani and G.M. Abouna

Part Ten: Bone Marrow Transplantation

55. Current status of allogeneic bone marrow transplantation Rainer Storb

56. New approach to bone marrow transplantation in thalassemia

G. Giardini, G. Lucarelli, M. Galimberti, P. Polchi, E. Angelucci, D. Garonciani, S.M.T. Durazzi, F. Agostinelli, M. Donati, C. Giorgi and M. Filocamo

57. Autologous bone marrow transplantation as treatment for bad-risk first remission acute lymphoblastic leukaemia

R.L. Powles, C.L. Smith and S. Milan

58. Conditioning regimens in bone marrow transplantation

R. Storb, F. Appelbaum, C. Badger, I. Bernstein, C.D. Buckner, F.B. Petersen, P. Martin, J. Hansen, C. Anasetti, B. Sandmaier, J. Bianco, F. Schuening and E.D. Thomas

59. The antileukaemic action of melphalan and total body irradiation in bone marrow transplantation

R.L. Powles, C.L. Smith, C. Tiley, M. Findley and M. O'Brien

60. Antifungal prophylaxis with fluconazole in bone marrow transplantation

R.L. Powles, C.L. Smith and S. Milliken

\section{Part Eleven: Xeno-Transplantation}

61. Mass islet isolation from the pancreas of higher mammals: a potential source for islet transplantation in diabetic patients

R.G. Bretzel, B.J. Hering and K.F. Federlin

62. The relationship of eicosanoids and complement components to hyperacute xenogeneic rejection and its modification by the PAF-antagonist WEB 2086BS 
David M. Saumweber, Rolf Bergmann, Claus Hammer and Walter Brendel

63. Antibody-induced rejection of established pig proislet xenografts in $\mathrm{CD}^{+} \mathrm{T}$ cell depleted diabetic mice

J. Dennis Wilson, Charmaine J. Simeonovic and Rhodri Ceredig

Part Twelve: Complications in Organ Transplantation

64. Occurrence of malignancies in immunosuppressed organ transplant recipients

Israel Penn

65. Transmission of cancer with donor organs

Israel Penn

66. Long-term experience with surgical repair for transplant renal artery stenosis

M.P. Posner, A.L. King, K.B. Brown and H.M. Lee

67. Lymphoproliferative disorders after liver transplantation (OLT): a recent experience

T.G. Heffron, J.C. Emond, J.R. Thistlethwaite, X.M. Rogiers, M.D. Yang, K.L. King and C.E. Broelsch

68. Experience with Kaposi's sarcoma in recipients of renal transplants in Tunisia

T. Ben Abdallah, A. El-Matri, C. Kechrid, R. Bardi, F. Ben Hamida, F. El-Younsi, H. Ben Maiz, F. Ben Ayed, Y. Gorgi and H. Ben Ayed

69. Urological complications in 510 consecutive renal transplants

H. Abdul Karim, M.S.A. Kumar, M. Samhan, P. John, I.M. Hassan, S. Abdul Basit, E.M. Philips and G.M. Abouna

Part Thirteen: Organ Procurement and Preservation

70. Preservation of the kidney and other organs into the nineties

G. Kootstra, R. Wijnen and J.G. Maessen

71. Clinical experience with liver preservation

Robert D. Gordon and Satoru Todo

72. Management of the organ donor

Yoogoo Kang

73. The role of the National Kidney Foundation in cadaveric transplantation in Saudi Arabia

S. Aswad, S. Taha, M. Babiker and A. Qayum 
xiv

Part Fourteen: Ethical, Legal and Religious Aspects

74. The position of the Transplantation Society on commercialization in organ transplantation

J.R. Batchelor

75. Ethics and transplantation: an analysis of 'rewarded gifting' John B. Dossetor

76. Moral, ethical and medical values sacrificed by commercialization in human organs

G.M. Abouna

77. Commerce and trade in human organs

B.N. Colabawalla

78. Some ethical concerns in organ transplantation

C.J. Vas

79. Islamic view on organ transplantation

Mohammed Ali Albar

Index of subjects 


\title{
48. Early observation in pancreas transplantation using the bladder drainage procedure
}

\author{
W.D. ILLNER, D. ABENDROTH, H. SCHNEEBERGER, \\ S. SCHLEIBNER, M. STANGL, J. THEODORAKIS, R. LANDGRAF \\ and W. LAND
}

Improved results in pancreas transplantation using the whole organ and a duodenal segment for diversion of exocrine secretion $(1,2)$ led to the introduction of this technique at the Munich Transplant Centre, too. This technique permits monitoring of the pancreatic exocrine secretion in the urine. There is accumulating suggestion that reduction in urine amylase activity might be an early marker of pancreatic allograft rejection. As an extension to our experience with the duct-occlusion technique we started a controlled study comparing both surgical techniques.

\section{Patients and methods}

So far 91 combined pancreas and kidney transplantation and 7 isolated pancreas transplantations have been performed using prolamine for duct occlusion. The bladder drainage technique was used in 16 diabetics, 11 simultaneously and 5 pancreas alone. Clinical results of our experience with the duct-occlusion technique have been published elsewhere (3).

\section{Donor and recipient operation}

The whole pancreas with spleen and a short duodenal segment is removed from the donor after complete in situ flushing using UW solution. In 4/16 organ procurements we harvested the whole pancreas together with the liver for grafting. Priority of vascular supply was given to the liver, consisting of the celiac axis plus an aortic patch and the portal vein. The whole pancreas graft includes the splenic artery, divided just distal to its origin on the celiac axis, superior mesenteric artery with an aortic patch and the remaining portal vein plus the superior mesenteric vein. After the Kocher maneuver a short duodenal segment is provided using a GIA stapler. The combined removal of liver and whole pancreas requires an arterial and venous reconstruction for the pancreatico- duodenal graft with the donor iliac vessels (4). The pancreatico- 
duodenal graft is placed intraperitoneally along the ascending colon with a transrectal incision. Arterial and venous anastomoses were carried out between the reconstruction pancreatic vessels and the recipient's external iliac vessels. For the bladder-duodenal anastomosis we use the two layer side-to-side technique (inner layer: running: 3/0 Vicryl and outer layer: interrupted 3/0 Vicryl).

\section{Immunosuppressive protocol}

Since 1984 a quadruple drug induction therapy is routinely used in pancreatic transplantation. It consists of CsA, Aza 'high' dose of steriods and ATG/ALG for a short period of time. Maintenance treatment consists of steriods, CsA and Aza for a period of 6 months, followed by double drug maintenance treatment with CsA and Aza.

More recently we have used a quadruple drug induction therapy with CsA, Aza, 'high' dose of steriods and ATG or OKT3 in a controlled study. The preliminary results were presented in Barcelona (5).

\section{Problems and complications according to different surgical techniques}

Using the duct-occlusion technique we are confronted with two major problems. Firstly, the occurrence of a primary irreversible venous thrombosis. Secondly, the development of a pancreatic fistula with the high risk of a secondary infection. The rate of this complication is shown in Table 1. The need of an anticoagulation therapy is required.

Despite of duct-occlusion with prolamine the residual exocrine secretion remains unsolved at the present time.

According to the new technique our clinical results show a hight incidence of intraparanchymal graft abscesses with subsequent loss of the pancreatic graft

Table 1. Early complications after stimultaneous pancreas and kidney transplantation.

\begin{tabular}{|c|c|c|c|c|}
\hline \multirow{2}{*}{$\begin{array}{l}\text { Surgical } \\
\text { technique }\end{array}$} & \multirow{2}{*}{$\begin{array}{l}\text { Venous } \\
\text { thrombosis }\end{array}$} & \multicolumn{2}{|c|}{ Local infection } & \multirow{2}{*}{$\begin{array}{l}\text { Pancreatic } \\
\text { fistula }\end{array}$} \\
\hline & & Intragraft & Perigraft & \\
\hline $\begin{array}{l}\text { Dust } \\
\text { occlusion } \\
(n=59)\end{array}$ & $\begin{array}{l}15 \% \\
(n=9)\end{array}$ & 0 & $\begin{array}{l}20 \% \\
(n=12)\end{array}$ & $\begin{array}{l}20 \% \\
(n=12)\end{array}$ \\
\hline $\begin{array}{l}\text { Bladder } \\
\text { drainage } \\
(n=11)\end{array}$ & 0 & $\begin{array}{l}36 \% \\
(n=4)\end{array}$ & $\begin{array}{l}18 \% \\
(n=2)\end{array}$ & 0 \\
\hline
\end{tabular}


(Table 1). This complication is very common in association with an urinary tract infection.

\section{Results}

Patients and graft survival probability rates for 1 year are comparable in both groups (Figures 1 and 2). Long-term results are demonstrable for the duct occlusion technique only (Figure 3).

\section{Summary}

Mortality and morbidity rates after pancreas transplantation are low and comparable in both groups talking into account that the number of patients transplanted using the bladder technique is still low and the observation period limited. The 1-year pancreas graft function rate is $60 \%$ in both groups. The early phase post-transplant using the duct obliteration in a segmental allograft bears the risk of an irreversible venous thrombosis and the development of a pancreatic fistula with subsequent graft loss. As a consequence of prolamine,

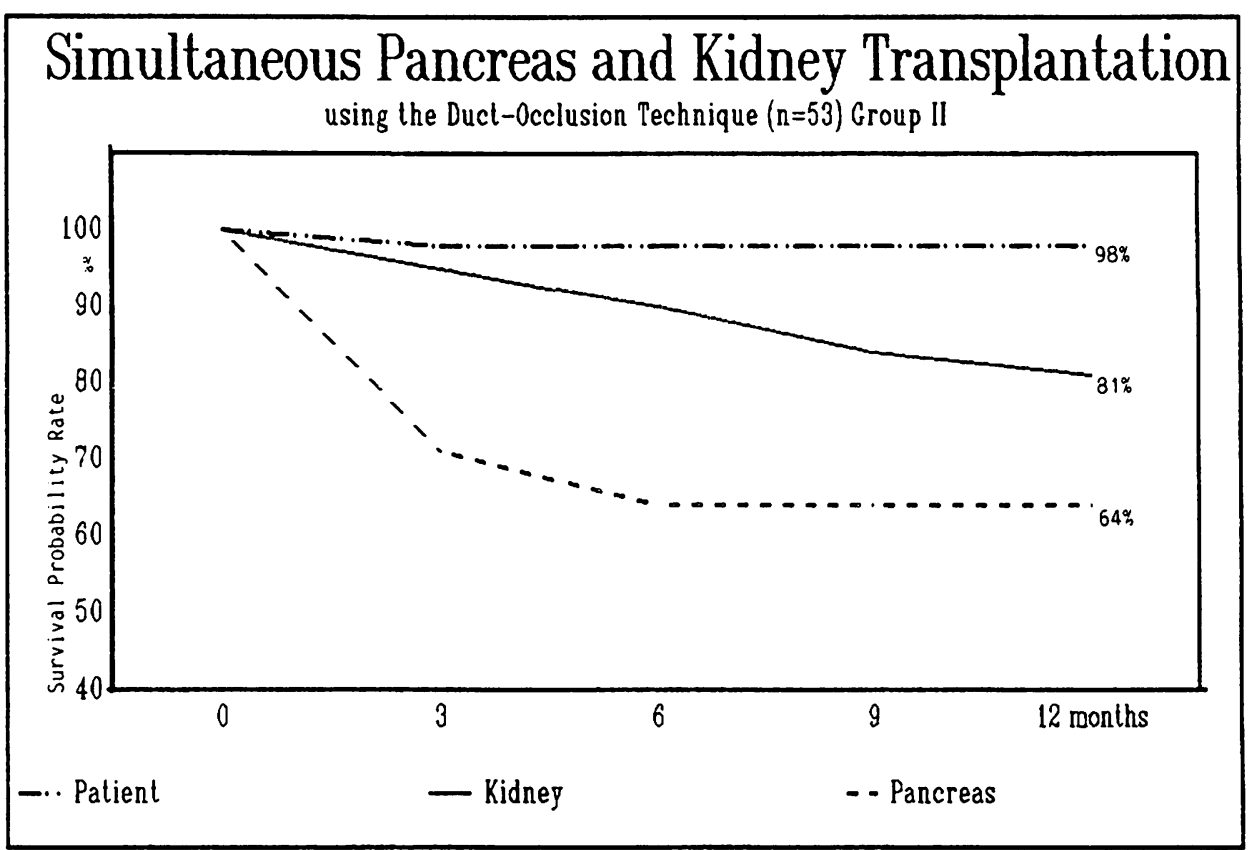

Fig. I. Patients and graft survival probability in stimultaneous pancreas and kidney transplantation using the duct-occlusion techniques $(n=53)$ (Cutler/Ederer formula). 


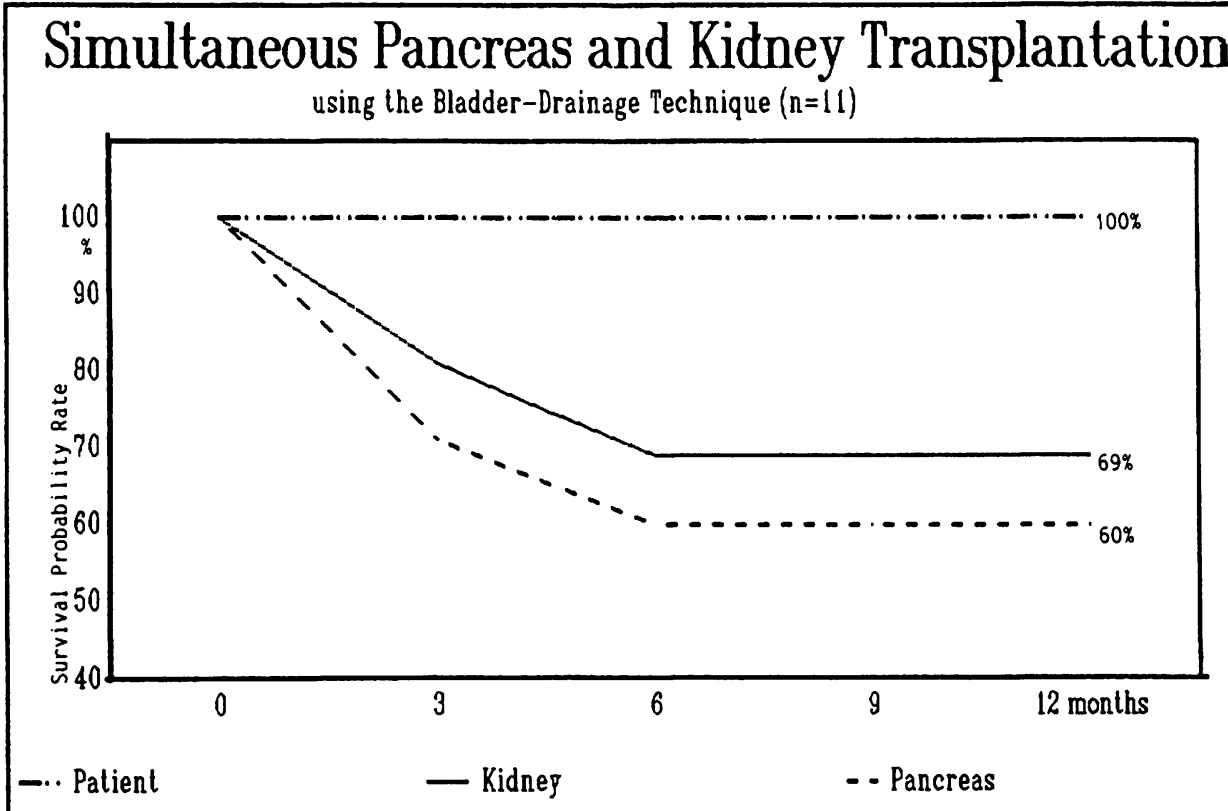

Fig. 2. Patient and graft survival probability in combined pancreas and renal transplantation using the bladder-drainage technique $(n=11)$ (Cutler/Ederer formula).

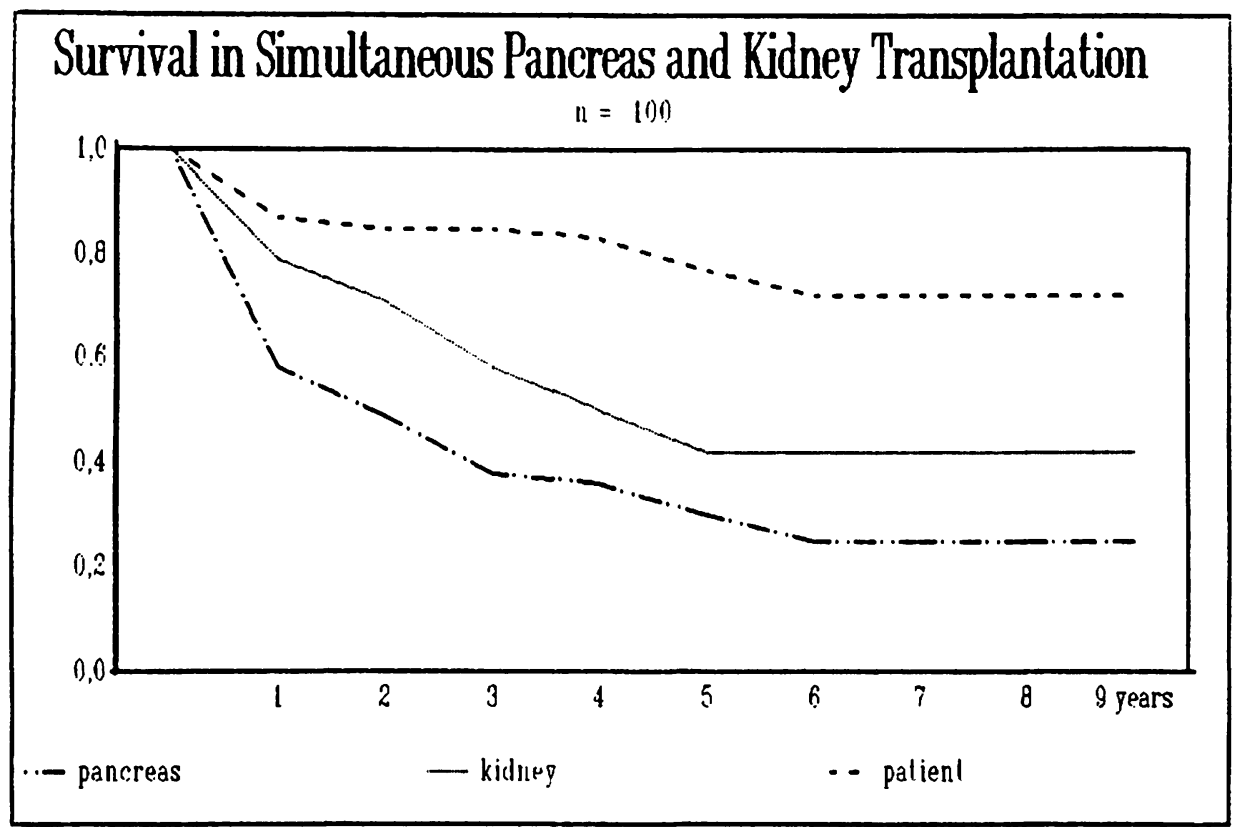

Fig. 3. Long-term results in simultaneous pancreas and kidney transplantation in duct-occluded segmental allografts $(n=100)$ (Cutler/Ederer formula). 
the result in the long-run is a vascularized islet cell graft without any exocrine activity and with no risk for the recipient. The induced destruction of exocrine tissue by prolamine is not associated with a deterioration of the endocrine function. Our early clinical observations with the bladder drainage show a remarkably high rate of local infection-complication following urinary tract infection also with subsequent graft loss. Patients with a history of bladder dysfunction as a side effect of long-term diabetic disease might therefore be better candidates for the duct-occlusion technique.

The surgical complication rate is acceptable. Still unsolved is the problem of a transplanted gland with an aggressive enzymatic secretion at the bladder mucosa, as well as for the recipient himself. With this technique postoperative complications may not only develop on the side of the pancreas but also from the duodenal segment. Further experience and long-term results must be gained to find out the best surgical technique.

\section{References}

1. Sollinger, H.W. and Belzer, F.O.: Pancreas transplantation with urinary tract drainage. In: C.G. Groth (ed.), Pancreatic Transplantation, pp. 131-146. W.B. Saunders (1988).

2. Corry, R.J.: Pancreatico-duodena transplantation with urinary tract drainage. In: C.G. Groth (ed.), Pancreatic Transplantation, pp. 147-168. W.B. Saunders (1988).

3. Land, W., Landgraf, W.-D., Illner et al: Clinical pancreatic transplantation using the prolamine duct occlusion technique. The Munich experience. Transplant. Proc. 19 (4, Suppl. 4), 75-83 (1987).

4. Gubernatis, G., Abendroth, D., Haverich, A. et al.: Technik der Mehrorganentnahme. In: Der Chirung, 59. Jg., Heft 7, 461-468 (1988).

5. Illner, W.-D., Theodorakis, J., Abendroth, D. et al.: Quadruple drug induction therapy in combined renal and pancreas transplantation - OKT3 versus ATG. Transplant. Proc. (in press). 